\title{
Impact Pandemic Covid-19 and Limitation Foods Pregnant Mothers Rural Papua Province of Indonesia
}

\author{
Semuel Piter Irab ${ }^{1} \quad$ Sarni Bela ${ }^{2}$ \\ Faculty of Public Health, Cenderawasih University Jayapura
}

\begin{abstract}
Background

Pandemic infectious diseases cause morbidity and deaths to increase over time globally. Corona virus disease-19 (Covid-19) is an infectious disease found in China in Wuhan City, and spread very quickly to Indonesia and Papua Province. The aims of the study was to determine the impact of the covid-19 pandemic and food limitations for rural pregnant mothers in Indonesia's Papua Province.

Methods

A cross sectional study design, is type research to see the relationship of the impact covid-19 pandemic and food limitations for rural pregnant mothers in Papua Province. Place of research Jayapura and Jayawijaya Regencies, which represents all the Regencies of Papua Province. The population ware all pragnant mothers in Papua Province. Samples were living in rural areas Jayapura and Jayawijaya Regencies. Data analysis using the ChiSquare test $\left(\chi^{2}\right)$.

Results

Covid-19 pandemic and food limitations of rural pregnant mothers in March - June 2020 in Papua Province. Food transportation was very less $33,7 \%$ and very good $26,7 \%$. Government helps was less $25,7 \%$ and good $36,6 \%$. Work of the head families were less $27,7 \%$ and good $24,8 \%$. Household heads income were very less $27,7 \%$ and very good $25,7 \%$. Limited of vitamins mineral source were very less $24,8 \%$ and very good $30,7 \%$. Protein sources $(10-15 \%)$ were less $38,6 \%$ and good $36,6 \%$.Carbohydrates source $(60-75 \%)$ less $27,7 \%$ and very good $37,6 \%$. Fats Source (10-20\%) were very less $37,6 \%$ and good $16,8 \%$. Energy sources $(2150$ to $2250 \mathrm{kcal}+300 \mathrm{kcal})$ were less $24,8 \%$ and good $28,7 \%$. Limitations food consumption of rural pregnant mothers were not significant with government helps, work of the head families, and the limitations mitamins mineral source.Limitations food consumption of rural pregnant mothers were significant with restrictions on food transportation, household heads income, limited of protein sources, carbohydrates, fats, and energy source.
\end{abstract}

Conclusion

There were no restrictions on government helps, work of the head families, and limited vimtamin mineral source. Impact pancemic covid-19 were limited to foods transportation, household head income, protein sources, carbohydrates, fats and energy.

Keywords : Impact pandemic covid-19, and limited foods pregnant mothers

DOI: $10.7176 / \mathrm{FSQM} / 100-06$

Publication date:August $31^{\text {st }} 2020$

\section{Background}

December 2019, Mysterious pneumonia cases were first discovered in Wuhan city, Hubei Province of China. According to reports from China that the transmission of mysterious diseases comes from markets fish and animals[1]. From 18 to 29 December 2019, there ware five patients suffering from mysterious illnesses. Strange symptoms caused by a respiratory disorder called Acute Respiratory Distress Syndrome (ARDS) [2].

In January 2020 the prevalence of respiratory disorders increased, or spread very quickly from Hubei Province, China, Japan, Korea, Thailand, Singapore, Indonesia, Europe, America, Africa, Australia, and become a serious problem in the world[3]. Based on the first World Health Organization research, this mysterious disease, called the novel 2019 coronavirus (2019-nCov). On February 11, 2020, World Health Organization announced the official name of this mysterious disease is Corona Virus Disease-19[2].

Pandemic infectious diseases cause morbidity and death to increase over time globally. Corona virus disease19 (Covid-19) was infectious disease found in China in Wuhan City, and spread very quickly to Indonesia and Papua Province. Up to June 9, 2020 the prevalence of covid-19 in Papua Province increased.

Data source for Papua Province Covid-19 Control, Prevention and Handling Task Force (09 June 2020). Peoples in Monitoring 51,1\%, Patients in Monitoring 12,8\%, patients positive 18,1\%, and treated 12,9\%, while $4,9 \%$ patients recovered and $0,2 \%$ died. Province Papua of positive patients increased 19 while those who recovered and died were lower than in March - June 2020. This causes a very large influence covid-19 on socioeconomic status in the Regencies/City in Papua Province of Indonesia[4].

Covid-19 has a big influence globally. Much damage to the economies of countries in the world. So many peoples did not work, did not had money, it is difficult to get food, and state income falls[5]. Covid-19 was one of the diseases that kills the world economy, so that causing unemployment to rise, people lose their jobs, and poverty 
were increasing widely throughout the world[6]. Thus covid-19 caused an economic recession to increase, from January to June 2020 as whole in the world, including the peoples of the Indonesian Papua Province.

An important part of the economic recession caused by the covid-19 pandemic was Indonesia's national food security in Papua Province. Foods security were very important and strategic part, because foods was basic human need to be able to live[7].

\section{Methods}

A cross sectional study design, was type of research to see relationship between the impact of the covid-19 pandemic and the limited foods availability of rural pregnant mothers in Papua Province[8]. The covid-19 impact caused restrictions on human activities and transportation, so foods supplies in the rural ware not as usual, before the covid-19 pandemic.

Thus pregnant mothers living in rural areas, consuming energy foods, and regulators that did not comply with the Nutrition Adequacy Rate (RDA).

Jayapura and Jayawijaya Regency research centers represent, all Regencies in Papua Province. Population were all pregnant mothers living in Papua Province, while the sample were pregnant mothers living in rural Jayapura Regency and Jayawijaya Regency. Data analysis using the Chi-Square test $(\chi 2)$.

\section{Results and Discussion}

Foods security was basically divided into three parts that were beneficial to society namely food availability, food consumption, food accessibility. Food availability is quite meaningful, the average amount and quality of food nutrition available in the community and market, sufficient the consumption needs of all households [9].

Foods were basic need for human life. Food is one of the basic needs that the body needs every day in a certain amount. Food as source of energy and human health. The amount of foods less or more consumed in a long time, can adversely affect the health status of the community[10].

Table 1. Distribution of Limited Foods Pregnant Mothers on the Rural Papua Province of Indonesian

\begin{tabular}{|c|c|c|c|c|c|c|c|c|}
\hline \multirow[b]{2}{*}{ Impact Pandemic Covid-19 on the } & \multicolumn{2}{|c|}{ Very less } & \multicolumn{2}{|c|}{ Less } & \multicolumn{2}{|c|}{ Good } & \multicolumn{2}{|c|}{ Very good } \\
\hline & $\mathrm{n}$ & $\%$ & $\mathrm{n}$ & $\%$ & $\mathrm{n}$ & $\%$ & $\mathrm{n}$ & $\%$ \\
\hline \multicolumn{9}{|l|}{ Restiction Socio-Economic status } \\
\hline - Food transportation & 34 & 33,7 & 19 & 18,8 & 21 & 20,8 & 27 & 26,7 \\
\hline - Government helps & 23 & 22,8 & 26 & 25,7 & 37 & 36,6 & 15 & 14,9 \\
\hline - Work of the head families & 26 & 25,7 & 28 & 27,7 & 25 & 24,8 & 22 & 21,8 \\
\hline - Household head income & 28 & 27,7 & 24 & 23,8 & 23 & 22,8 & 26 & 25,7 \\
\hline \multicolumn{9}{|l|}{ Limitations of Nutrition Sources } \\
\hline - Vitamin \& mineral source & 25 & 24,8 & 19 & 18,8 & 26 & 25,7 & 31 & 30,7 \\
\hline - Protein source $(10-15 \%)$ & 9 & 8,7 & 39 & 38,6 & 37 & 36,6 & 16 & 15,8 \\
\hline - Carbohydrate source $(60-75 \%)$ & 17 & 16,8 & 28 & 27,7 & 18 & 17,8 & 38 & 37,6 \\
\hline - Fats source $(10-20 \%)$ & 38 & 37,6 & 33 & 32,7 & 17 & 16,8 & 13 & 12,9 \\
\hline - Energy source $(2150$ to $2250 \mathrm{kcal})+300 \mathrm{kcal}$ & 18 & 17,8 & 25 & 24,8 & 29 & 28,7 & 29 & 28,7 \\
\hline
\end{tabular}

Explanation : 1. Foods transportation Rural (Cars, trucks and motorcycles)

2. Work of the head families rural (farmers, fishermen, unskilled laborers, and private)

Restrictions on the socioeconomic status of rural pregnant mothers, in the covid-19 pandemic in March - June 2020 in Papua Province. Foods transportation very less 33,7\%, and very good 26,7\%. Government helps were less $25,7 \%$ and good $36,6 \%$. Work of the head families less $27,7 \%$ and good $24,8 \%$. Household head income very less $27,7 \%$ and very good $25,7 \%$.

Limitations of the Nutrition Sources pregnant mothers in rural Papua Province of Indonesia. Limited of vitamins mineral source was very less $24,8 \%$ and very good $30,7 \%$. Protein source $(10-15 \%)$ were less $38,6 \%$ and good $36,6 \%$. Carbohydrates source (60-75\%) less $27,7 \%$ and very good $37,6 \%$. Fats source (10-20\%) was very less $37,6 \%$ and good $16,8 \%$. Energy source (2150 to $2250 \mathrm{kcal}+300 \mathrm{kcal})$ less $24,8 \%$ and good $28,7 \%$. Health protocol in the social restrictions of the community with social distancing, physical distancing, work from home, large-scale eradication, and regional quarantine, adversely affect household food availability in Papua Province.

A person's health condition depends on the level food consumption. Level consumption was determined by the quality and quantity of nutritious food. The quality of food shows the fulfillment of all nutrients needed by the body. While the quantity indicates the amount of each nutrient to the body's needs. If the composition of food dishes, meet the needs of the body both in quality and quantity, then the body will get adequate nutrition[11].

Indonesia Law number 18 of 2012. Food security is a condition of fulfilling foods for the country to the individuals, reflected by the availability of sufficient food, both in quantity and quality, safe, diverse, nutritious, evenly distributed, and affordable and not contrary to religion, beliefs, and community culture, for a healthy, active and productive sustainable life. The description shows that food security is one of the primary human needs, which must be realized for human life[12]. 
Nutritional status is foods security outcome that description a person's quality of life. The number of children under five experiencing malnutrition and malnutrition is an indicator of nutrient prone. Many toddlers and pregnant mothers suffer from malnutrition and malnutrition is an indicator of nutritional vulnerability [13]. While poor nutrition is influenced by many interrelated factors. The reason is the consumption of unbalanced food and infectious diseases, inadequate food supplies and inadequate parenting, as well as sanitation/clean water, and basic health services are inadequate[14].

Based on Republic of Indonesia Government Regulation number 21 year 2020, about large-scale social restrictions, in order to accelerate the handling of corona virus disease 2019 (Covid-19). Covid-19 pandemic with number of cases and/number of deaths, has increased and expanded across regions cross country and impact on the political, economic, social, cultural, defense and security aspects, as well as the welfare of the peoples in Indonesia[15].

Table 2. Relationship Impacts Pandemic Covid-19 and Limited Foods Pregnant Mothers of Rural Papua Province Indonesian

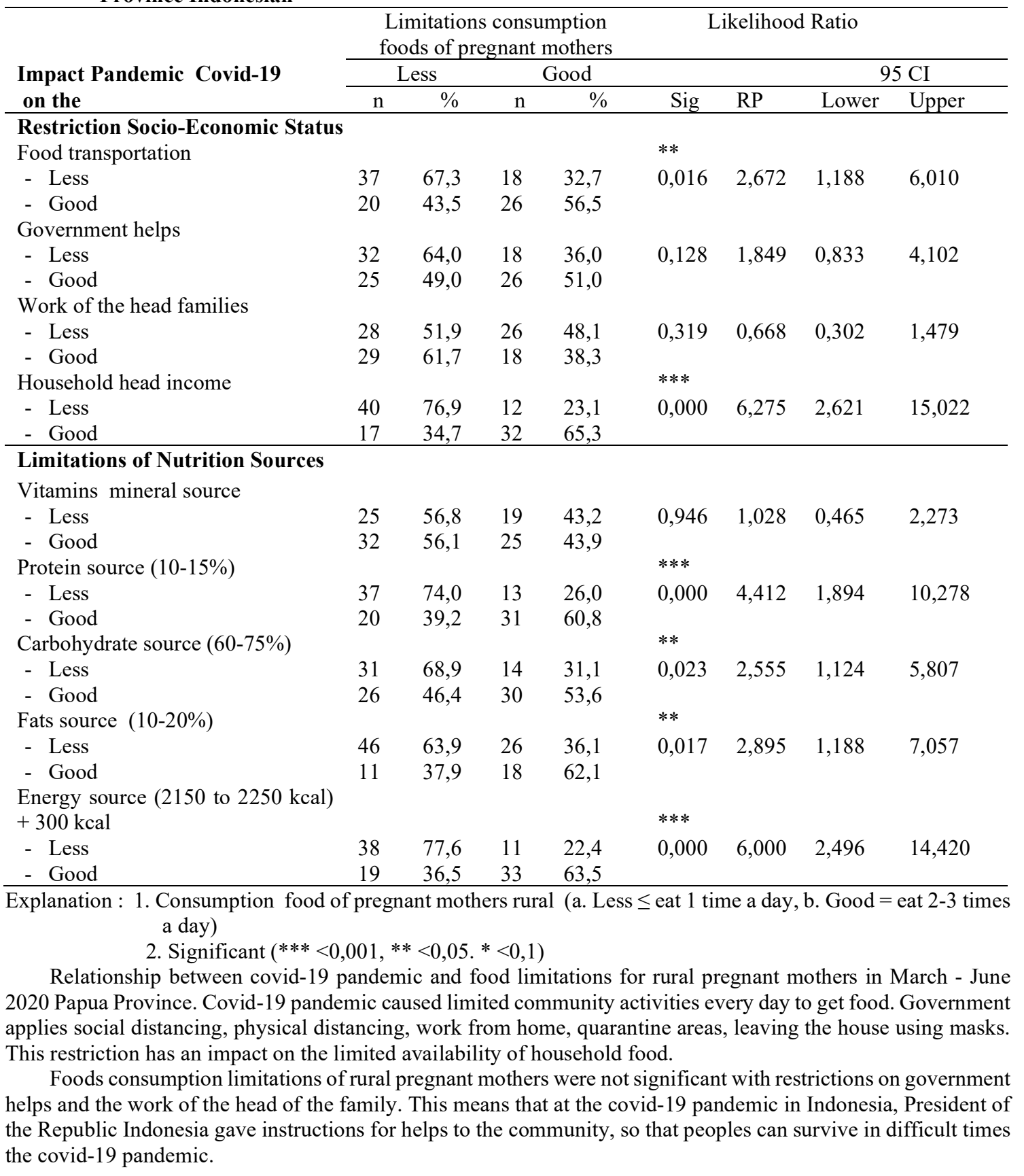


Covid-19 pandemic in Papua Province, peoples in urban areas had more restricted working hours. Whereas rural communities work hours were not restricted. Results showed that the food consumption limitations of rural pregnant mothers were not significant with government helps, work of the head families, and vitamins mineral sources. This means that restrictions on rural communities in working as farmers, fishermen, unskilled laborers, the private sector are not restricted. Because covid-19 prevalence in Papua Province was higher in urban areas compared to very small in rural.

Foods consumption limitations of rural pregnant mothers were significant with restrictions on food transportation and family head income. This means with implementation of regional quarantine during the covid19 pandemic in Papua Province, the transportation relationship between urban and rural areas was limited, in order to prevent covid-19 transmission.

In addition, the limitation food consumption of rural pregnant mothers were significant with restriction of the household's head income. This means that agricultural products, fisheries, unskilled laborers and the private sector do not work, causing family head to not had income to meet the family's living needs. Thus of the head families in rural has a limited income and it was very difficult to make ends meet.

Covid-19 and it's impact on agriculture and global food security. In the agricultural sector, employment declined from $40,2 \%$ to $26,8 \%$. Counting $60,4 \%$ were families with low income [16]. The covid-19 pandemic, Europe's workforce has decreased drastically, as a result of job losses in hundreds thousands of seasonal workers. This happened in France, Germany, Italy, Spain and Poland. Thus, many peoples do not work, do not had income, and do not had sufficient food supplies[17].

Improving the country's food security was very important by way of community empowerment. Because the community is empowered by the government, it is very important in maintaining the food and nutrition vigilance system in the region[18].

Food-insecure families, basically having children under five are more at risk of malnutrition, whereas families that were not food insecure have children who are not malnourished. One of the problems related to the problem of public food insecurity is the worldwide covid-19 pandemic. One of the problems related to community food insecurity was worldwide covid-19 pandemic[19]. Foods availability in an area was a major factor in preventing cases of malnutrition in the community. One problem of malnutrition that needs special protection is the first 1000 days of live birth. Starting from pregnant women to children less than 2 years in regencies/Cities in Indonesia[20].

Limited of nutrition sources for rural pregnant mothers in the pandemic covid-19 Papua Province. The results showed that the foods consumption limitations of rural pregnant mothers were not significant with government helps, work of the head families, and limited of vitamins mineral sources. This means that peoples who live in rural Papua province in general, had sources food ingredients and the availability sufficient food ingredients. Thus there were no limitation foods ingredients for rural pregnant mothers, for the adequacy of nutrient intake during the covid-19 pandemic.

Foods were very important for pregnant mothers, one of the functions foods was to provide endurance and prevent infectious diseases. This is very related to family behavior and habits. Eating habits of pregnant mothers will follow the family behavior in every meal. Family behavior of providing food for pregnant mothers and toddlers were very influential on the nutritional status was more, less, and normal[21].

Nutritionally aware families play a huge role in providing nutritious food for family members. Nutrition aware families research in Yapen Islands Regency, The results show that the nutritional status of children were very dependent on the behavior of families providing nutritious food for family members. Where toddlers less nutrition is found in families who were not aware of nutrition[22].

Impact pandemic covid-19 and limited nutritional resources of rural pregnant mothers in Papua Province. The food consumption limitations of rural pregnant mothers were significant with restrictions food transportation and families head income. This means that pregnant mothers living in rural Papua Province, in the pandemic covid-19 caused the government to restrict transportation and employment, so that the head family works as unskilled laborers, the private sector, farmers and fishermen do not had income. Thus the needs of pregnant mothers were not fulfilled during the covid-19 pandemic in Papua Province.

Pandemic Covid-19 and limited nutritional resources of pregnant mothers rural. The results showed that the limitation foods consumption of pregnant mothers was significant with protein sources (10-15\%), carbohydrates $(60-75 \%)$, fats (10-20), and energy source $(2150$ to $2250 \mathrm{kcal}+300 \mathrm{kcal})$. This means that nutritious food source was very important to improve the nutritional status of pregnant mothers in the pandemic covid-19. The immune system of pregnant mothers against infectious diseases and the status of the baby in the womb, very depends on the intake nutritious food trimesters 1, 2, and 3, and the health status of pregnant mothers were good.

Changes in the nutritional status of the community, is one of the important behavioral changes, in utilizing food, according to the social outlook of the community. Thus the growth and development of nutritional status in pregnant women, breastfeeding mothers, and toddlers are closely related to the community's view, provide nutritious food for theirs family[23]. Cultural knowledge in social relations greatly influences the degree of public health. This relates to how to provide food for the family, and ways to prevent infectious diseases in public 
culture[24].

Pathogenesis of malnutrition consists of 5 stages. First, the inadequacy of nutrients lasts for a long time. Second, the nutrient reserves in the tissues are used to meet inadequacy. This situation lasts a long time, will be a deterioration of tissue, which was characterized by weight loss. Third, there was biochemical change that can be detected by laboratory examination. The fourth was occurrence of changes in bodily functions in the presence of distinctive signs. The fifth is the occurrence of anatomic changes, which can be seen from the appearance of classical signs, so that it has an impact on malnutrition[25].

Nutritional status of pregnant women and children under five is very important in building quality Human Resources in the countries of the world. Nowadays, developing countries, especially Asia and Africa, public health nutrition issues that fear stunting children, is the main problem that causes low human resources. so that the government prepares more collaborative or cross-sectoral programs that can reduce stunting[26].

Covid-19 in Papua Province increased from March to June 2020. Causing decreased food security in Papua Province Regency/City. In addition there are limited differences in food supply between urban and rural areas. Thus the covid-19 pandemic caused an economic crisis and food security was greatly felt in urban communities.

Covid-19 has a big influence globally. Much damage to the economies of the world countries. So many people do not work, do not have money, it is difficult to get food, and state income falls. Covid-19 is one of the diseases that kills the world economy, causing unemployment to rise, people losing jobs, and poverty is increasing widely throughout the world. Thus covid-19 caused an economic recession to increase from December 2019 to June 2020 as a whole in the world, including peoples in Papua Province.

High risk groups, the community must get good protection by the Government of the Papua Province. One of the nutrition-prone groups, in the co-19 pandemic in Papua Province is the group of pregnant women, breastfeeding mothers, and toddlers. This group needs special negotiations from the Provincial Government of Papua, so that this group is protected from poor nutrition and malnutrition. Regencies/City Region in Papua Province is a threat of poor nutrition and malnutrition, due to the covid-19 pandemic.

Thus the role of nutrition workers in the community health center, and the Regencies/City Health Office of the Papua Province, many needed support in community nutrition surveillance. To find out the poor nutrition of mothers and childrens in the community, and preventive action early. If not found early, can be an iceberg phenomenon that causes the prevalence of Less Chronic Energy. and Low Birth Weight (LBW) increased in Papua Province. Thus the First 1000 Days of Life or Window off Oppotunity will fail, and cannot be fixed in the future, and is permanent(irreversible).

Suggestions to the Government of the Papua Province are every pregnant woman, breastfeeding mother, and child under five. Minimum of every meal 2 times and a maximum of 3 meals. Do not pregnant women, breastfeeding mothers and toddlers eat 1 time a day or do not eat in one day. This can cause the nutritional status of pregnant women, breastfeeding mothers, and children under five worsening from day to day in Papua Province.

Food should be pregnant women, breastfeeding mothers, and toddlers containing enough 3 substances, namely (1) energy substances: sago, taro, banana, cassava and others), (2) Builders: freshwater fish, sea water fish and chicken eggs, (3) regulating substances: cooked papaya, watermelon, star fruit, mango, cooked banana, spinach, mustard greens, vegetable wax, papaya leaves, kale, cabbage, carrots and others. In order for adequate intake of nutrients in pregnant women, breastfeeding mothers, and toddlers in Papua Province can achieve normal nutritional status.

Nutritious food is a priority for pregnant women. Consumption of foods low in nutrients, adversely affects anemia in pregnant women. The resulting output is babies born with low birth weight ( $<2500$ grams). Thus, pregnant women who give birth to low birth weight children, have low quality human resources. In addition, children born with low body weight $<2500$ grams, have poor development[27].

Based on the basic issues of the theory human development, that nutritious food is very influential on increasing human resources. Peoples who have good intelligence were born to mothers who have normal nutritional status. This is a measure in increasing the human resources of countries in the world. Thus the normal nutritional status of pregnant women, breastfeeding mothers, infants and toddlers becomes an important part in the quality of life of the nation[28].

nutrition is a process of organisms using food that is consumed normally through the process of digestion, absorption, transportation, storage, metabolism, and removal of substances that are not used. Nutritional functions are sourced from food to maintain life, growth, and normal functions of the body's organs, and produce energy. Nutritional state is a result of the balance between consumption and absorption of nutrients and use of nutrients. While malnutrition is a pathological condition due to deficiency or excess, both relative and absolute nutrition [29].

Food and Agriculture Organization (FAO), reported that between 2010 - 2012, there were almost 900 million peoples or as many as $12,5 \%$ of the total world population experiencing malnutrition. This problem is high in middle and low income countries. Most malnutrition occurs in women and childrens [30]. Under the nutritional food supplementation program for pregnant women and children under five in the United States, the results show that nutritional food supplementation in pregnant women and children under five even though it has not reached 
$100 \%$, but only by $20 \%-40 \%$, but can reduce the prevalence of malnutrition children from $1976-1980$ [31].

Poor nutrition when pregnant women and malnutrition when children aged 0-24 months, can not be corrected if the child has become an adult[32]. The results of the study (Aryastami, 2015), that the role of maternal nutrition is very important for the health status of the baby[33]. Whereas Marotz (2012) states that early growth and development of infants can be stunted, because the baby receives essential nutrients is very little compared to what should be needed[34].

Malnutrition is still a special concern, and its handling is step by step, and sustainability by the government, so that children in Indonesia can grow up healthy to be the nation's golden generation that is free from chronic nutritional disorders (stunting). Collaboration with other sectors, is one of the strategies to realize the highest changes for the quality of a healthy, prosperous and independent life, for all Indonesian people in the future[35].

\section{Conclusion}

Pandemic Covid- 19 March-June 2020 in Regencies/City of Papua Province. The impact limited food consumption in rural pregnant mothers were not significant with the limitation of government helps, work of the head families, and the limitations vitamin mineral resources.

limitations foods consumption of rural pregnant mothers were significant with restrictions on food transportation, families head income, and protein sources (10-15\%), carbohydrates (60-75\%), fats (10-20\%), and energy source $(2150$ to $2250 \mathrm{kcal}+300 \mathrm{kcal})$.

\section{Bibliography}

1. Rothan HA, Byrareddy SN(2020). The epidemiology and pathogenesis of coronavirus disease (COVID-19) outbreak. J Autoimmun. 2020; published online March 3. DOI: 10.1016/j.jaut.2020.102433.

2. Ren L-L, Wang Y-M, Wu Z-Q, Xiang Z-C, Guo L, Xu T, et al(2020). Identification of a novel coronavirus causing severe pneumonia in human: a descriptive study. Chin Med J. 2020; published online February 11. DOI: $10.1097 / \mathrm{CM} 9.0000000000000722$.

3. Huang C, Wang Y, Li X, Ren L, Zhao J, Hu Y, et al(2019). Clinical features of patients infected with 2019 novel coronavirus in Wuhan, China. Lancet. 2020;395(10223):497-506.

4. Papua Province task force (2020). Covid-19 Control, Prevention and Handling Task Force in Papua Province.

5. Ozeli.P \& Arun. T, (2020). Spillover of COVID-19 : Imapct on the Global Economy. Central Bank of Nigeria and University of Essex United Kingdom.

6. Baldwin.R \& Mauro.B.W.Di. (2020). Economics in the Time of Covid-19. AvoxEU. Org BOOK.

7. Suryana.A. (2004). Food Security in Indonesia. Food Security and Nutrition in the Era of Regional Autonomy and Globalization. National Food and Nutrition Workshop VIII. Jakarta, May 17-19, 2004.

8. Practices A.W. (2003). Fundamentals of Medical \& Health Research Methodology. PT Raja Grafindo Persada. Jakarta.

9. Soekirman (2000). Nutrition and its application for families and communities. Jakarta: Director General of Higher Education Ministry of National Education.

10. Muchtadi D. (2001) Prevention of over nutrition and chronic diseases through improved food consumption patterns. Bogor: Bogor Agricultural University.

11. Sediaoetama (2006). Nutrition for professions and students Volume I and II. Jakarta: Dian Rakyat.

12. Ariani, M. and Pitono, J. (2014). Diversification of Food Consumption: Performance and Future Perspectives. Food Diversification and Transformation of Agricultural Development. Editor: Ariani, M et al. Agricultural Research and Development Agency, Ministry of Agriculture. Jakarta.

13. Anonymous (2013). Directorate General of Nutrition and KIA Ministry of Health Republic of Indonesia.

14. Anonymous. (2016). Nutrition Status Monitoring Handbook and Nutrition Performance Indicators in 2015, Directorate of Community Nutrition, Directorate General of Public Health, Ministry of Health Republic of Indonesia.

15. Presidential Decree. (2020). Republic of Indonesia Government Regulation number 21 year 2020 regarding Large-Scale Social Restrictions in the Framework of Accelerating the Management of Corona Virus Diasease 2019 (Covid-19).

16. International Labour Organization (2020). Lapangan kerja berdasarkan jenis kelamin dan aktivitas ekonomi - perkiraan menggunakan model dari ILO, November 2019.

17. Reuters .(2020). No bed of roses: East Africa's female flower workers lose jobs as coronavirus hits exports", 11 April 2020; Martinplaut, "Tens of thousands of African jobs at risk as Europe dumps flowers during the Coronavirus crisis", 22 March 2020

18. Sirajuddin, Surmita, Astuti.T. (2018). Center for Health Human Resource Education. Health Human Resources Development and Empowerment Agency. 2018 edition. Ministry of Health Rebuplik Indonesia. Jakarta

19. International Food Policy Institute(2020). COVID-19 : Trade Restriction are worst possible response to 
safeguard food security. 27 March 2020.

20. Irab.S.P., Djuwita.R., Besral, Utari.D.M., Kusharisupeni. (2018). Coverage of Basic Health Programs and Regional Fiscal Capacities Indices With Stunted Prevalence Change in 2007-2013 on Childrens Under Five Years of Regencies/Cities in Indonesia. Indian Journal of Applied Research. Volume-8.June-2018.

21. Dovey T.M (2010). Eating Behaviour. Mc Graw Hill, Open University Press.

22. Irab.S.P., Bouway D. Y., Sokoy F. (2015). The Relationsip Between Education, Employment, Income and Avoid Food Behavior With Famili Nutrition Women Aware of Children in Southern District Yapen Island Indonesia in 2013. University of Cenderawasih Papua Indonesia. Sept.2015.Vol.5,No.7. www.ijsk.org/ijrss.

23. Irab.S.P. (2019). The Relationship between Changes in Coverage of Health and Social Programs with Changes in Prevalence of Toddler Stunting in Regencies / Cities in Indonesia from 2007 to 2013. Faculty of Public Health Doctor of Public Health Study Program University of Indonesia (Dissertation)

24. Irab.S.P. (2009). Social, Economic, Cultural, and Knowledge Relationships, Kadarzi Attitudes in FKMCenderawasih University Students. Postgraduate Program, Faculty of Medicine, Gadjah Mada University Yogyakarta (Thesis)

25. Jelliffe, DB., \& Jelliffe, E. (1989). Community Nutritional Assesment with Special Reference to Less Technically Developed Countries. Oxford: Oxford University Press.

26. UNICEF. (2013). Improving child nutrition: the achievable imperative for global progress. In New York: UNICEF.

27. Morris.J.C. (2011). Dietitian's Guide to Assessment and Documentation. Jones and Bartlett Publishers. Sudbury, Massachusetts. Boston, Toronto, London, Siggapure.

28. Papalia.D.E \& Martorell.G. (2015). Experience Human Development. Thirteenth Edition. Mc Graw-Hill Education.

29. Gibson, R. (2005). Principles of Nutritional Assesmen ((2nd Edition)., Ed.). United State Of America. New Yorks: Oxford University Press.

30. Beesabathuni, K., van Zutphen, K. G., \& Kraemer, K. (2017). Role of Foundations and Initiatives by the Private Sector for Improving Health and Nutrition. In Nutrition and Health in a Developing World (pp. 771790). Springer.

31. Lewit, E. M., \& Kerrebrock, N. (1997). Population-based growth stunting. The Future of Children, 149-156.

32. SUN. (2010). a Frame Work for Action. Public-Prive Partnerships.

33. Aryastami. (2015). Early Age Growth Determines Pre-Puberty Age Growth (Longitudinal Study of IFLS 1993-1997-2000), Dissertation. Depok: Faculty of Public Health UI.

34. Marotz, L. R. (2012). Health, Safety, and Nutrition for the Young Child. Kansas: University of Kansas.

35. Ministry of Health. (2018). The Situation of Short Toddler (Stunting) in Indonesia. Jakarta: Data and Information Center Window Bulletin Ministry of Health Republic of Indonesia. Ministry of Health Republic of Indonesia. 